\title{
Diversity and activity of epiphytic nitrogen-fixers on standing dead stems of the salt marsh grass Spartina alterniflora
}

\author{
Pia H. Moisander ${ }^{1,2, *}$, Michael F. Piehler ${ }^{1}$, Hans W. Paerl ${ }^{1}$ \\ ${ }^{1}$ University of North Carolina at Chapel Hill, Institute of Marine Sciences, 3431 Arendell Street, Morehead City, \\ North Carolina 28557, USA \\ ${ }^{2}$ Present address: Ocean Sciences Department, University of California Santa Cruz, 1156 High Street, Santa Cruz, \\ California 95064, USA
}

\begin{abstract}
Microbial communities growing on the surfaces of standing dead stems of salt marsh grasses contribute to fixation of atmospheric nitrogen $\left(\mathrm{N}_{2}\right)$ in these N-limited intertidal systems. Salt marshes in North Carolina, USA, have been shown to exhibit $\mathrm{N}_{2}$ fixation throughout the growth season, but the composition of these diazotrophic communities is poorly known. This study investigated the diversity of the epiphytic $\mathrm{N}_{2}$-fixing microbial community on the surfaces of dead stems (shoots) of the cord grass Spartina alterniflora in a salt marsh in North Carolina. Sequencing of the nifH gene and microscopy showed that a diverse diazotrophic community consisting of at least 8 diazotrophic cyanobacterial taxa, as well as an assemblage of $\alpha-, \gamma$-, and $\delta$-proteobacteria, was present. Half of the recovered unique nifH sequences fell into the cluster with anaerobes. $\mathrm{N}_{2}$-fixation rates under natural

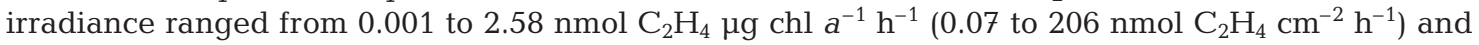
decreased from spring to fall. Nitrogen-fixation rates had a positive relationship with chlorophyll $a$, suggesting phototrophs contributed to $\mathrm{N}_{2}$ fixation. The dominant diazotrophs in this study differed from epiphytic communities described elsewhere in the southeast United States, suggesting regional differences are present in the diversity of these communities.
\end{abstract}

KEY WORDS: NifH $\cdot$ Nitrogen fixation · Epiphytes $\cdot$ Salt marsh $\cdot$ Spartina alterniflora $\cdot$ Cyanobacteria $\cdot$ Anaerobes · Diversity

\section{INTRODUCTION}

Chronic nitrogen $(\mathrm{N})$ shortages in aquatic ecosystems create many opportunities for dinitrogen $\left(\mathrm{N}_{2}\right)$ fixing (diazotrophic) communities to compete effectively. There are numerous examples of successful $\mathrm{N}_{2}$-fixing communities playing key roles in $\mathrm{N}$ cycling in coastal aquatic ecosystems. Nitrogen often limits productivity in coastal salt marshes in North America (Valiela 1983, Covin \& Zedler 1988). Nitrogen fixation has been found to be present in these environments both on sediment and plant surfaces and in the rhizosphere of the salt marsh grasses (Carpenter et al. 1978, Jones 1982, Langis et al. 1991, Lovell et al. 2000). Epiphytes (surface communities) of standing dead shoots (stems) of the salt marsh grass Spartina alterniflora may include diazotrophic communities (Newell et al. 1992, Currin \& Paerl 1998a, Lovell et al. 2001). Epiphytes can play an important role in salt marsh N-cycling and can be a source of energy for higher trophic levels (Currin et al. 1995). The microbial community responsible for $\mathrm{N}_{2}$ fixation in these environments is not well characterized. Specifically, the contribution of cyanobacteria to $\mathrm{N}_{2}$ fixation in these communities is uncertain. Among South Carolina and Georgia salt marsh epiphytes, cyanobacteria do not appear to be important (Newell et al. 1992, Lovell et al. 2001), while in marshes in North Carolina, cyanobacteria are usually abundant (Currin \& Paerl 1998b). The main goal of this study was to 
investigate the diversity of the diazotrophic community associated with standing dead $S$. alterniflora stems in a North Carolina marsh, in order to allow cross-system comparisons.

Determining the identities of organisms and groups of organisms responsible for cycling of elements such as nitrogen and sulfur has led to an improved understanding of the dynamics of these microbially mediated cycles. Genes responsible for many important microbial biogeochemical transformations, including $\mathrm{N}_{2}$ fixation, have been identified and utilized in characterizing mixed microbial communities in microbial mats and epiphytes (Zehr \& McReynolds 1989, Zehr et al. 2003). The nifH gene encodes the dinitrogenase reductase protein in the nitrogenase complex, responsible for $\mathrm{N}_{2}$ fixation. NifH is evolutionarily highly conserved and generally coherent with 16S rRNA phylogeny, allowing it to be used in phylogenetic analyses (Zehr et al. 2003). As a functional gene, nifH is important in characterizing diazotrophic microbial communities in environmental samples, because this gene can be used as a marker for elucidating the community structure of microbes sharing a common function (i.e. $\mathrm{N}_{2}$ fixation).

Responses of $\mathrm{N}_{2}$ fixation to environmental factors have been investigated in epiphytes growing on standing dead stems of salt marsh grasses in coastal North Carolina, USA (Currin et al. 1995, Currin \& Paerl 1998a,b). This investigation was undertaken in order to learn more about these communities by characterizing the community structure of diazotrophs in one of the marshes in this region. We employed rate measurements, phylogenetic analysis of the nifH gene, and microscopic analyses to characterize diazotrophic community composition and activity. Salt marshes play a central role in elemental cycling at the coastal land-water interface worldwide. By describing salt marsh microbial communities in different geographical locations we will learn how both climate and human impact affect these systems.

\section{MATERIALS AND METHODS}

Sampling and experimental design. The sampling site was a salt marsh in Beaufort, North Carolina. The marsh is representative of natural systems in the area. Samples were collected every 4 to $8 \mathrm{wk}$ from 24 April to 17 October in 2002 during low tide at ca. 09:00 to 10:00 h. Dead standing shoots (stems) of Spartina alterniflora were cut at the sediment level. Stems were transported to the University of North Carolina at Chapel Hill Institute of Marine Sciences (IMS) located about $8 \mathrm{~km}$ from the study site. The daytime incubations were immediately started upon arrival at the
IMS, while the stems for evening incubations were planted upright in sediment in a shallow dish, and during the day and early evening the stems were subjected to rising and falling water levels, respectively, mimicking the natural tides. Incubations for the determination of $\mathrm{N}_{2}$ fixation were carried out at 12:00 to $16: 00 \mathrm{~h}$ (day) and ca. 20:00 to 00:00 h (evening), under natural irradiation in open tanks with running seawater. The time of evening incubations varied slightly, in order to always start them after dusk.

Nitrogen fixation. Nitrogen-fixation rates in the diazotrophic community were investigated by acetylene reduction assay. In order to help clarify the contributions of different $\mathrm{N}_{2}$-fixing groups, the potential variability in $\mathrm{N}_{2}$ fixation in response to light and the time of day was also studied. For the acetylene reduction assay, stems were cut into $5 \mathrm{~cm}$ length and put into $60 \mathrm{ml}$ serum vials that were then sealed with red rubber serum stoppers. Ten $\mathrm{ml}$ of air were replaced with acetylene. Eight replicate vials were kept under natural irradiance, while another 8 were kept in the dark. Two different kinds of blanks were prepared. Four acetylene blanks were serum vials without any stems, but had $10 \mathrm{ml}$ of air phase replaced with acetylene. Four stem blanks consisted of serum vials with stems, but without acetylene. Serum vials were incubated for $4 \mathrm{~h}$ in a seawater bath outside the IMS. After incubation, $3.5 \mathrm{ml}$ of gas was transferred to evacuated blood collection tubes (Vacutainers). Ethylene concentration was measured on the Vacutainer contents the following day, using a Shimadzu GC-9A gas chromatograph equipped with a flame ionization detector and a Porapak $\mathrm{T}$ stainless steel column at $80^{\circ} \mathrm{C}$, using $\mathrm{N}_{2}$ as a carrier gas. The gas chromatograph was calibrated daily using ethylene standards. To allow intercomparisons with other studies, acetylene reduction values are presented both normalized to chlorophyll a (chl a) concentration and normalized to mean stem surface area. Mean stem surface area was calculated from measurements of the diameters of 10 stems. For each sampling month and each treatment (day-light, day-dark, evening-dark), a 1-way analysis of variance (ANOVA) was carried out (SPSS 9.0 software). A 2way ANOVA was carried out to test for interaction effects of sampling month and incubation treatment. Bonferroni pairwise comparisons were carried out for cases in which $\mathrm{p}<0.05$ for the ANOVA. The relationship between $\mathrm{N}_{2}$-fixation rates and chl a was tested using linear regression. Normality and homogeneity of variances were checked, and data were transformed if necessary to meet the test assumptions.

Chlorophyll a and microscopy. After the gas was collected from serum vials for ethylene measurement, the stems were split in half along the vertical axis. One-half was frozen $\left(-20^{\circ} \mathrm{C}\right)$ for chl a analysis. The 
other half was immersed in $5 \mathrm{ml}$ of seawater from the sampling site (filtered through $0.2 \mu \mathrm{m}$ Durapore filters) and fixed with Lugol's solution for microscopic analysis. For chl a analysis, stems were extracted overnight with a solvent mixture containing methanol (45\%), acetone $(45 \%)$, and water $(10 \%)$, after sonication in ice twice for $1 \mathrm{~min}$ with a tip sonicator. The extract was filtered (GF/F filters, Whatman) to remove particles, and the chl a concentration was determined using a fluorometer (Turner TD-700) (Welschmeyer 1994). Samples were screened for absence or presence of cyanobacteria, using a Nikon Eclipse 800 phase contrast microscope at $200 \times$ or $400 \times$ magnification, and recorded using a Nikon Coolpix 900 digital camera. Cyanobacteria were identified according to Komárek (2003) and Komárek et al. (2003). Small non-heterocystous filamentous cyanobacteria are difficult to identify, and therefore we did not attempt it for all of the filaments we observed. Certain features in filament morphology, however, allowed us to make rough groupings. These features include: (1) filament end (pointy or flat), (2) presence or absence of sheath, (3) cell shape and size, (4) cell attachment to each other (no separation between cells or clear separation between cells), or (5) filament-coiling characteristics (straight, curved, coiled).

DNA extraction, nifH PCR, and sequence analysis. Stems for nifH analysis were kept dry until processing, up to $2 \mathrm{~h}$ from sampling. Epiphytes from 10 to 15 stems were scraped with a scalpel into $1 \mathrm{ml}$ of TE $(10 \mathrm{mM}$ Tris, 1 mM EDTA, pH 8.0) buffer each and stored at $-20^{\circ} \mathrm{C}$ until extraction. All surface material around each stem was saved. For extraction, 4 samples per sampling month (April, July, and September) were defrosted and washed with TE buffer 2 to 3 times before treatment with Dnazol (Ambion). After $3 \mathrm{~h}$ of incubation at $90^{\circ} \mathrm{C}$, samples were bead-beaten for $3 \mathrm{~min}$, after which the incubation was continued for another 1 to $2 \mathrm{~h}$, followed by a second bead-beating. Samples were extracted with chloroform, the DNA was precipitated with ethanol, and resuspended in deionized water. DNA was purified as follows. To $100 \mathrm{ml}$ of sample, $800 \mu \mathrm{L} 2$ wash buffer (Paul 2001) and $200 \mu \mathrm{l}$ isopropanol were added. The samples were spun through Dneasy Plant kit (Qiagen) spin columns. The columns were washed with L2 buffer and AW buffer (Dneasy Plant kit) and eluted with $150 \mu \mathrm{l}$ of preheated $\left(50^{\circ} \mathrm{C}\right) \mathrm{TE}$ buffer. Then, $100 \mu \mathrm{l}$ of $5 \mathrm{M} \mathrm{NaCl}$ and $320 \mu \mathrm{l}$ isopropanol were added to the elute, spun for $20 \mathrm{~min}$ to precipitate, washed with $1 \mathrm{ml}$ ethanol, and resuspended to $100 \mu \mathrm{l}$ TE buffer. An approximately $380 \mathrm{bp}$ section of the nifH gene was amplified using primers from Olson et al. (1998). One set of primers targeted cyanobacteria, and the second set targeted aerobic and microaerophilic bacteria. Separate PCRs were carried out for the 2 primer sets. The PCR reaction mix consisted of $5 \mu \mathrm{l}$ of DNA polymerase $10 \times$ buffer (Promega), $1 \mu \mathrm{l}$ of each $50 \mu \mathrm{M}$ primer, $1 \mu \mathrm{l}$ of $10 \mathrm{mM}$

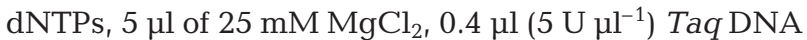
polymerase (Promega), and $34.6 \mu \mathrm{l}$ water. Then, $2 \mu \mathrm{l}$ DNA extract was added as template. Amplification consisted of 30 cycles with $1 \mathrm{~min}$ at $94^{\circ} \mathrm{C}, 1 \mathrm{~min}$ at $53.5^{\circ} \mathrm{C}$, and $1 \mathrm{~min}$ at $72^{\circ} \mathrm{C}$, and a $7 \mathrm{~min}$ final extension step at $72^{\circ} \mathrm{C}$. PCR products were run on a $1 \%$ agarose gel, excised, and cleaned using the Qiagen gel extraction kit. The cleaned PCR products were cloned using the TA cloning kit (Invitrogen). The plasmids were isolated using the QIAprep Miniprep kit. Sequencing was carried out by the University of North Carolina at Chapel Hill Automated DNA Sequencing Facility on a 3100 Genetic Analyzer (Applied Biosystems). The sequencing reaction was done using the ABI PRISM BigDye Terminator Cycle Sequencing Ready Reaction Kit with AmpliTaq DNA Polymerase, FS (Applied Biosystems). Nucleotide sequences were edited and translated for phylogenetic analysis using BioEdit (Hall 1999). Multiple alignment for the observed sequences and for selected sequences from GenBank was carried out using Clustal X software. Phylogenetic trees were generated by PAUP* 4 Beta Version 10 (Swofford 1998). A neighbor-joining tree with bootstrap analysis of 1000 repetitions was generated. Bootstrap values $>50$ are reported. GenBank accession numbers for sequences from this study are shown in Fig. 1.

\section{RESULTS AND DISCUSSION}

Nitrogen input from $\mathrm{N}_{2}$ fixation is quickly incorporated into the plant biomass in salt marshes (Dakora \& Drake 2000), supporting the general observations of $\mathrm{N}$ limitation in salt marshes (Valiela 1983) and underscoring the importance of diazotrophic communities in alleviating $\mathrm{N}$ deficiency in these systems. However, the fate of $\mathrm{N}$ incorporated by $\mathrm{N}_{2}$ fixation associated with dead marsh grass stems is less clear than that incorporated by $\mathrm{N}_{2}$ fixation in rhizospheres or epiphytes of live plants. In this study, $\mathrm{N}_{2}$-fixation rates were the highest in the spring and early summer (Fig. 2, Table 1). The $\mathrm{N}_{2}$-fixation rates ranged from 0.001 to $2.58 \mathrm{nmol} \mathrm{C}_{2} \mathrm{H}_{4} \mu \mathrm{g} \mathrm{chl} a^{-1} \mathrm{~h}^{-1}$ (0.07 to $206 \mathrm{nmol}$ $\mathrm{C}_{2} \mathrm{H}_{4} \mathrm{~cm}^{-2} \mathrm{~h}^{-1}$ ) over the study period. Sampling month and treatment had an interaction effect ( $p=0.010$, 2way ANOVA). The decrease in $\mathrm{N}_{2}$-fixation rates from spring to summer and fall was most prominent in the treatments that were incubated in the light during the day (Fig. 2). While in the day-light treatment $\mathrm{N}_{2}$ fixation remained similar from July to October, there was a decreasing trend in $\mathrm{N}_{2}$ fixation in response to the other 2 treatments. Other studies on seasonal $\mathrm{N}_{2}$ fixation on 


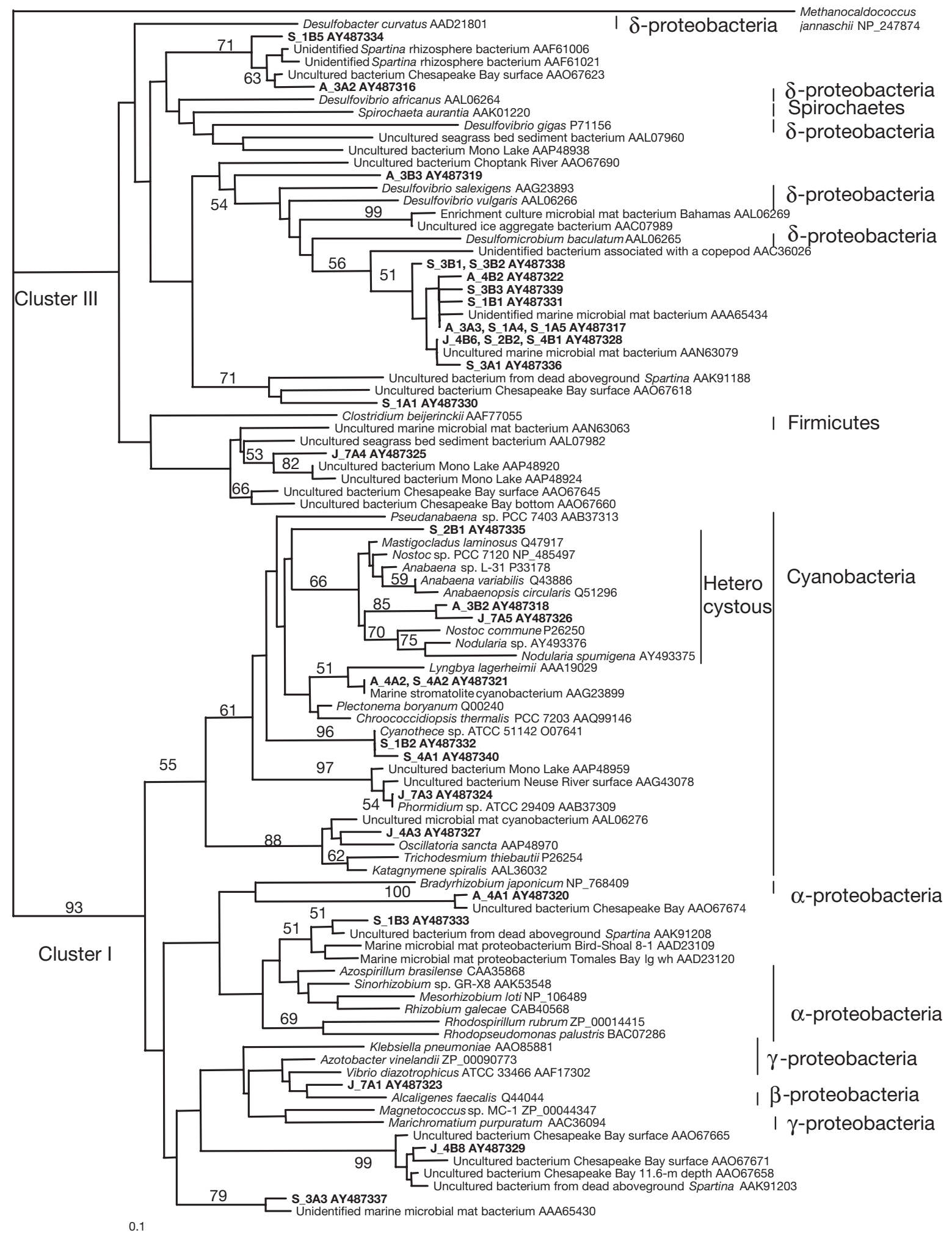

Fig. 1. A phylogenetic tree based on partial nifH amino acid sequences from Spartina alterniflora epiphytes, and environmental and cultured bacterial sequences from the GenBank database. The names of clones and GenBank accession numbers for sequences from the present study are shown in bold. The first letter (A, J, or S) in clone names refers to sampling month (April, July, or September, respectively). The tree was generated using the neighbor-joining method. Bootstrap values of 1000 simulations are given for the major branches. Bootstrap values $>50$ are shown. The archaeon Methanocaldococcus jannaschii (Methanococcus jannaschii) was used as an outgroup. Bacterial groups are indicated on the right 


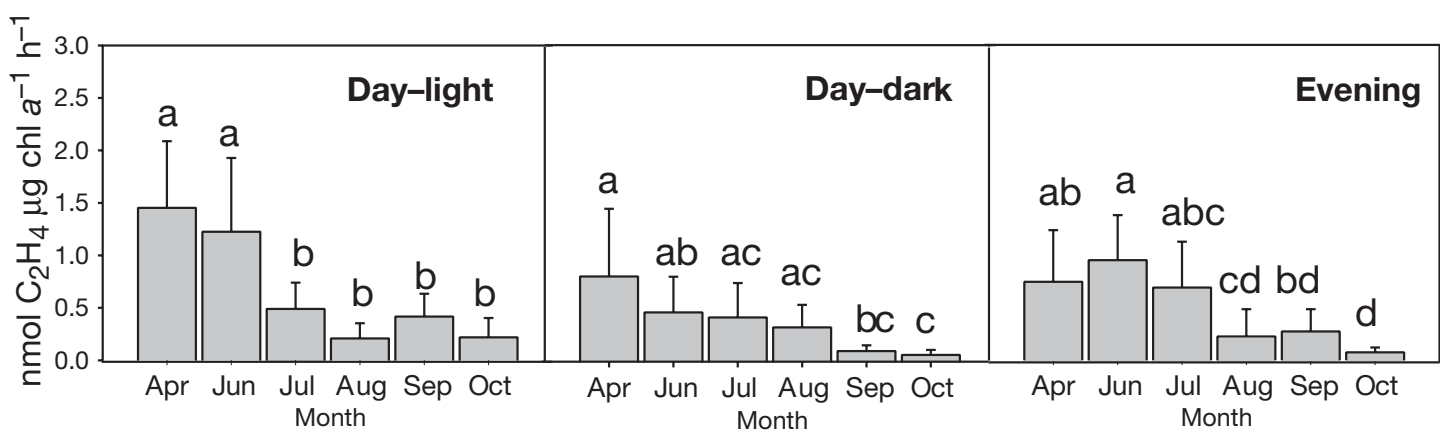

Fig. 2. Nitrogen fixation measured by the acetylene reduction assay from April to October 2002. $\mathrm{N}_{2}$ fixation is shown separately for each treatment. Letters show pairwise comparisons between months from 1-way ANOVAs carried out separately for each treatment. Different lower case letters indicate significant differences at $\alpha=0.05$ level (Bonferroni pairwise comparisons)

salt marshes have also shown highest $\mathrm{N}_{2}$-fixation rates in the spring or summer (Carpenter et al. 1978, Jones 1982, Currin \& Paerl 1998b, Tyler et al. 2003). Seasonal changes and differences among studies may be partly due to variability in temperature or shading conditions, and may reflect latitude or other geographic factors. Chlorophyll a remained at relatively similar levels from April to September, but was reduced in October (Table 1). There was a positive relationship between chl $a$ and $\mathrm{N}_{2}$ fixation when all data were pooled over the study period $\left(r^{2}=0.173, p=0.000, n=129\right)$ (Fig. 3 ). Though this significant relationship is weak, it is worthy of discussion, especially considering it is in a benthic system where patchiness is high. One reason for the positive relationship between chl $a$ and $\mathrm{N}_{2}$ fixation rates could be that cyanobacteria were partially responsible for the $\mathrm{N}_{2}$ fixation in the system. If this is true, a direct relationship between the 2 would not be expected, since a large proportion of the epiphytic microalgal community consisted of diatoms and other eukaryotes, and their contribution to the community was highly variable, temporally and spatially. It is also possible that high rates of primary production fuel the activity of heterotrophic diazotrophic bacteria by producing labile carbon (Bebout et al. 1993). Whatever

Table 1. Chlorophyll a $\left(\mu \mathrm{g} \mathrm{cm} \mathrm{cm}^{-2}\right.$ ) and $\mathrm{N}_{2}$ fixation (acetylene reduction, $\mathrm{nmol} \mathrm{C}_{2} \mathrm{H}_{4} \mathrm{~cm}^{-2} \mathrm{~h}^{-1}$ ). Means and standard deviations (SD) of all treatments ( $\mathrm{n}=16$ to 28 ) are shown for each sampling month

\begin{tabular}{|lcccc|}
\hline \multirow{2}{*}{ Month } & \multicolumn{2}{c}{ Chl a } & \multicolumn{2}{c|}{$\mathrm{N}_{2}$ fixation } \\
& Mean & SD & Mean & SD \\
\hline Apr & 53.6 & 20.2 & 56.5 & 44.1 \\
Jun & 84.2 & 22.1 & 72.1 & 48.8 \\
Jul & 64.2 & 23.2 & 34.2 & 26.6 \\
Aug & 75.0 & 34.8 & 16.3 & 12.8 \\
Sep & 79.8 & 23.7 & 17.1 & 12.1 \\
Oct & 35.3 & 11.9 & 4.6 & 5.3 \\
\hline
\end{tabular}

the mechanistic linkage is between these 2 processes, the results indicate increased primary productivity in these systems will promote $\mathrm{N}_{2}$ fixation.

Nitrogen-fixation rates were highly variable among individual stems (Fig. 2), as evidence of patchiness. In June, September, and October, $\mathrm{N}_{2}$-fixation rates during the day were higher in the light than in the dark. Most of the time the rates did not show clear differences among incubation conditions (light during the day, dark during the day, or dark during the evening) (Fig. 2). Elevated $\mathrm{N}_{2}$-fixation rates during the day in light suggest contribution to $\mathrm{N}_{2}$ fixation by heterocystous cyanobacteria that can fix $\mathrm{N}_{2}$ while their own photosynthesis is active and oxygen is present in the environment, or activity of photosynthetic, chemotrophic, or heterotrophic diazotrophs (Paerl et al. 1994). The presence of $\mathrm{N}_{2}$ fixation in the dark during

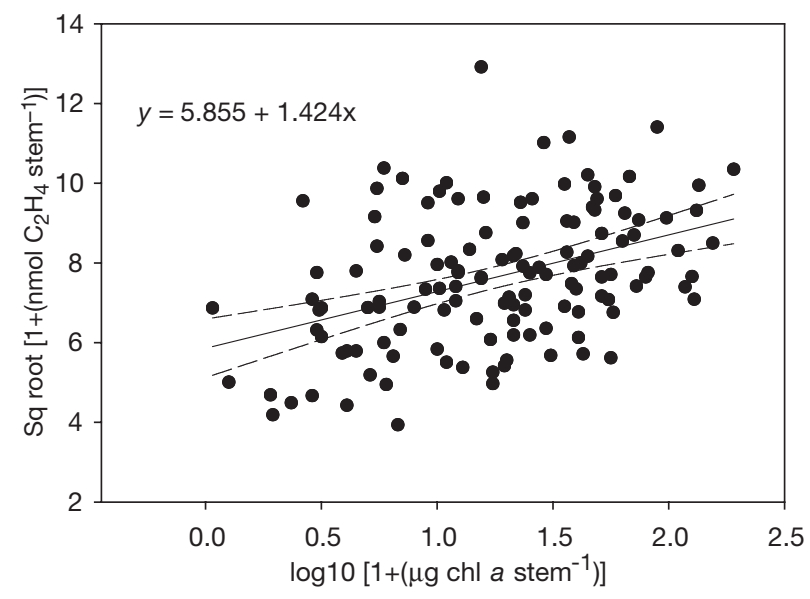

Fig. 3. Nitrogen-fixation (acetylene reduction) rates (nmol $\mathrm{C}_{2} \mathrm{H}_{4}$ stem $\left.^{-1}\right)$ in relationship to chlorophyll a $\left(\mu \mathrm{g} \mathrm{stem}{ }^{-1}\right)$ during the study. Data from all replicates in all treatments are included from all sampling months. The data were transformed as shown to give normal distribution. Linear regression (continuous line) and 95\% confidence intervals (dashed lines) are shown $\left(\mathrm{r}^{2}=0.173, \mathrm{p}=0.000, \mathrm{n}=129\right.$ ) 
the day and in the evening suggests contributions to $\mathrm{N}_{2}$ fixation by non-heterocystous cyanobacteria, chemotrophs, or heterotrophs. Non-heterocystous cyanobacteria often require microaerophilic or anoxic conditions for $\mathrm{N}_{2}$ fixation, and, thus, carry out their $\mathrm{N}_{2}$ fixation during dark hours, when oxygen levels are reduced in the environment, and they can promote the low oxygen conditions themselves by increasing their respiration rates (Postgate 1987, Bergman et al. 1997). Oxygen conditions in the environment overall have an important effect on which microbial groups are actively fixing $\mathrm{N}_{2}$ (Postgate 1987, Burris \& Roberts 1993). As groups, autotrophic and heterotrophic bacteria can contribute to $\mathrm{N}_{2}$ fixation, both in the light and in the dark (Paerl \& Zehr 2001). As several microbial groups could potentially fix $\mathrm{N}_{2}$ in all of the treatments, it is not possible to conclude which groups were responsible for $\mathrm{N}_{2}$ fixation in each treatment. Oxygen profile measurements in the stem epiphytes would be useful in learning about the functions of different groups.

From the total of 35 sequenced clones (of 62 clones total), 25 nifH sequences were unique among the sequences from the system, revealing considerable diazotrophic diversity. Both primer sets used amplified both cyanobacterial and non-cyanobacterial nifH sequences. A phylogenetic analysis of the nifH sequences showed that the sequences grouped with non-heterocystous and heterocystous cyanobacteria and with $\alpha_{-}, \gamma_{-}$, and $\delta$-proteobacteria (Fig. 1). The tree was dominated by nifH Clusters I and III (Chien \& Zinder 1994, Zehr et al. 2003). Bootstrap values supported Cluster I at high probability, but the support for Cluster III was $<50 \%$. Cluster I consists of cyanobacteria and a variety of $\alpha-, \beta-$, and $\gamma$ proteobacteria, while strict anaerobes and sulphate reducers group together as Cluster III, in spite of relatively low similarity at the DNA level (Zehr et al. 1995). Several clones sequenced in April, July, and September clustered together (Cluster III) and grouped with the $\delta$-proteobacteria. The majority of them fell into their own node with previously sequenced marine microbial mat bacteria. These sequences showed relatively close relationships with known sulphate reducers. Between 89 and $90 \%$ of the residues in the nifH peptide sequences in this group were similar to the known sulphate reducer Desulfomicrobium baculatum. Other related sequences in Cluster III included sequences from a Spartina alterniflora rhizosphere, Chesapeake Bay water column, marine sediments, Mono Lake, an ice aggregate, and bacteria associated with a copepod. An identical sequence, grouping with anaerobes, was observed from April and September samples (Clones A_3A3, S_1A4, and S_1A5), and another one was found both in July and September (J_4B6, S_2B2, S_4B1), suggesting certain groups are present in the system throughout the growth season. Sulphate reducers are known to be important $\mathrm{N}_{2}$ fixers in sediments of many salt marshes (Rooney-Varga et al. 1998, Nielsen et al. 2001, Gribsholt \& Kristensen 2003, Hamersley \& Howes 2003, Purdy et al. 2003); therefore, finding presumptive sulphate reducers among $S$. alterniflora epiphytes is not a great surprise. The high sequence diversity of the epiphytes that grouped within the cluster with anaerobes suggests that anaerobes may play a role in $\mathrm{N}_{2}$ fixation in the epiphytes of this salt marsh system; however, further studies are needed to verify nifH expression. The dead shoots in marshes often accumulate sediment, and therefore microbes such as sulphate reducers that commonly contribute to $\mathrm{N}_{2}$ fixation in marine sediments are likely to be found in epiphytes as well. Reduced oxygen tensions can be found in degrading S. alterniflora material, enhancing conditions for $\mathrm{N}_{2}$ fixation by microaerophiles and possibly anaerobes (Paerl \& Prufert 1987).

A few sequences grouped with known $\alpha-, \beta-$, and $\gamma$ - proteobacteria (Fig. 1) in Cluster I, containing presumptive microaerophiles, obligate aerobes, and anoxygenic phototrophs. Additionally, sequences in Cluster I from this study grouped with previously characterized uncultivated or unidentified marine bacteria from the Chesapeake Bay water column, salt marshes in South Carolina (associated with dead Spartina alterniflora biomass), and marine microbial mats.

Microscopic and nifH analyses showed that at least 8 distinct potentially $\mathrm{N}_{2}$-fixing cyanobacterial taxa were present in the system (Fig. 1, Table 2). Based on microscopic observations, the non-heterocystous types dominated throughout the study period, while heterocystous cyanobacteria were observed only rarely. Non-heterocystous Lyngbya sp., Phormidium spp., and narrow, unidentified non-heterocystous types were found throughout the season in microscopic analyses. Non-heterocystous Oscillatoria sp., tentatively identified Jaaginema sp. (Komárek et al. 2003), and several types of distinct unidentified non-heterocystous filaments were observed. Two unidentified types of heterocystous cyanobacteria were observed by microscopy. Merismopedia sp. and other unidentified, potentially diazotrophic, coccoid cyanobacteria were observed. Additionally, pennate diatoms were present in high numbers at all sampling times, and certain other unidentified eukaryotic algae were consistently present. A high abundance of photosynthetic epiphytes is also evident from the chl a concentrations (in individual stems from 16 to $180 \mu \mathrm{g} \mathrm{chl} \mathrm{a} \mathrm{cm}^{-2}$, means shown in Table 1). NifH gene sequence analysis matched and complemented microscopic observations of cyano- 
Table 2. Cyanobacteria identified by microscopy

\begin{tabular}{|c|c|}
\hline Month & Observations of cyanobacteria \\
\hline Apr & $\begin{array}{l}\text { Phormidium sp. 1, very common } \\
\text { Unidentified heterocystous }\end{array}$ \\
\hline Jun & $\begin{array}{l}\text { Lyngbya sp., common } \\
\text { Non-heterocystous filamentous, tentatively } \\
\text { identified as Jaaginema sp. }\end{array}$ \\
\hline Jul & $\begin{array}{l}\text { Arthrospira sp./Spirulina sp. } \\
\text { Lyngbya sp., varying widths, common } \\
\text { Oscillatoria sp., common } \\
\text { Phormidium sp. 1, common } \\
\text { Phormidium sp. } 2 \\
\text { Four types of unidentified, filamentous, narrow, } \\
\text { non-heterocystous } \\
\text { Unidentified filamentous non-heterocystous, } \\
\text { separated oval cells } \\
\text { Unidentified heterocystous }\end{array}$ \\
\hline Aug & $\begin{array}{l}\text { Lyngbya sp., very common, often in aggregates } \\
\text { Phormidium sp. 1, common } \\
\text { Phormidium sp. 2, individual filaments and } \\
\text { aggregates with Lyngbya sp. } \\
\text { Four types of unidentified, filamentous, narrow, } \\
\text { non-heterocystous } \\
\text { Coccoid cells in aggregates with Lyngbya sp. }\end{array}$ \\
\hline Sep & $\begin{array}{l}\text { Arthrospira sp./Spirulina sp. } \\
\text { Lyngbya sp. } \\
\text { Merismopedia sp. } \\
\text { Phormidium sp. } 1 \\
\text { Six types of unidentified, filamentous, narrow, } \\
\text { non-heterocystous }\end{array}$ \\
\hline Oct & $\begin{array}{l}\text { Lyngbya sp. } \\
\text { Oscillatoria sp., common } \\
\text { Phormidium sp. 1, very common } \\
\text { Unidentified, filamentous non-heterocystous }\end{array}$ \\
\hline
\end{tabular}

bacteria. A sequence that had a $95 \%$ peptide sequence identity with Lyngbya lagerheimii was observed both in April and September. At least 2 sequences from presumptive heterocystous cyanobacteria were observed. Several sequences were found that had 100\% identical peptide sequences with previously sequenced environmental samples or cultures. These included Cyanothece (GenBank Accession No. O07641, American Type Culture Collection [ATCC] Strain 51142), Phormidium sp. (GenBank Accession No. AAB37309, ATCC Strain 29409), a marine stromatolite cyanobacterium (AAG23899), and an uncultured bacterium from a microbial mat (AAN63079). In addition, a sequence with $95 \%$ identity with Oscillatoria sancta was found. Several sequences showed 99\% identities among sequences from uncultured organisms from this study and from the GenBank. The Cyanothece sp. ATCC 51142 type strain shows a highly regulated temporal pattern in its daily $\mathrm{N}_{2}$ fixation, with $\mathrm{N}_{2}$ fixation occurring only in the dark and nitrogenase not functioning in the light when photosynthesis is active (Schneegurt et al. 1994), following a 'typical' diel pattern of a non-heterocystous cyanobacterium (Bergman et al. 1997). Our detection of an identical nifH sequence in our study marsh suggests such $\mathrm{N}_{2}$-fixation patterns are present and contribute to the $\mathrm{N}_{2}$-fixation rates observed in the dark in these systems. Reports of both Cyanothece spp. and Phormidium spp. from epiphytic communities in salt marshes are rare (Currin \& Paerl 1998a).

There were some seasonal patterns in observed and potential $\mathrm{N}_{2}$-fixing communities. Highest rates of $\mathrm{N}_{2}$ fixation were from April to August, and rates were considerably reduced in October. Sequences from most clones in April and September grouped with anaerobes, while sequences from July were evenly distributed to all groups. There were also some shifts in dominant cyanobacteria during the study period (Table 2). Lyngbya sp. was present from June to October, and was frequently the dominant cyanobacterium. Phormidium sp. 1 was another highly abundant cyanobacterium in the system throughout the study, and a second Phormidium sp. was observed in July and August only. Oscillatoria sp. shifted from high abundances in July and October to absence during other months. Dominance by Lyngbya sp. and Phormidium spp. in North Carolina salt marshes was reported in a previous study (Currin \& Paerl 1998a), in which the heterocystous Calothrix sp. was reported as another dominant species. In contrast, observations of heterocystous species were rare in this study. These differences may reflect not only seasonal changes, but also spatial patchiness in marshes or marsh developmental stage (Piehler et al. 1998), factors that should be further investigated. Community differences are likely to affect $\mathrm{N}_{2}$-fixation rates, which in this study were on the order of 10-fold as high as reported by Currin \& Paerl (1998b), but similar to rates reported by Piehler et al. (1998) for the eastern North Carolina salt marshes.

The epiphytic community described in this study was somewhat different from communities in South Carolina and Georgia marshes, associated with dead aboveground Spartina alterniflora biomass (Lovell et al. 2001). We had highest recovery of sequences in presumptive anaerobes and cyanobacteria from our North Carolina study site, in contrast to a community dominated by the $\alpha$-proteobacterial sequences described by Lovell et al. (2001) in South Carolina and Georgia marshes. These differences reflect different nifH primers and may be affected by the different epiphyte recovery methods used in these studies, but they also appear to be influenced by geographic differences. In spite of the presence of cyanobacteria on clay films on stem surfaces, this surface film was not always the locus of $\mathrm{N}_{2}$ fixation in Georgia marshes (Newell et al. 1992), while heterotrophic bacteria within the degrading stems were possibly the primary $\mathrm{N}_{2}$-fixers in this 
system. In contrast, Currin \& Paerl (1998b) found that the majority of $\mathrm{N}_{2}$ fixation in stems in North Carolina was associated with epiphytes comprised of cyanobacteria and other microbes. Further work is needed to quantify the relative contribution of different diazotrophs to $\mathrm{N}_{2}$ fixation and $\mathrm{N}$ budgets in various salt marshes.

Although the presence of a gene does not equal its expression, it is likely that a diverse community of diazotrophs contributes to $\mathrm{N}_{2}$ fixation in the study marsh. The consistent presence of diazotrophic cyanobacteria and a positive relationship between chl $a$ and $\mathrm{N}_{2}$ fixation suggest that cyanobacteria contribute to $\mathrm{N}_{2}$ fixation in this system. The relative contribution of cyanobacterial $\mathrm{N}_{2}$ fixation to the total salt marsh $\mathrm{N}_{2}$ fixation is likely to differ geographically and temporally. It is dependent on factors such as clay content (Newell et al. 1992), turbidity, shading (Carpenter et al. 1978), temperature, as well as tidal elevation, relating to desiccation stress (Currin \& Paerl 1998b). Because $\mathrm{N}_{2}$ fixation must be supported by organic carbon supplied either by an exogenous (heterotrophs) or endogenous (autotrophs) source, variability in light, temperature, and external supplies of carbon and nutrients directly affect the activity of these communities and consequently affect the community composition. Overall, inputs of $\mathrm{N}, \mathrm{P}$, and $\mathrm{C}$ into these systems are likely to regulate $\mathrm{N}_{2}$-fixation rates and community structure of the diazotrophic organisms. Diazotrophy is frequently a more important $\mathrm{N}$-input process in newly constructed or restored than in natural marshes (Langis et al. 1991, Piehler et al. 1998, Tyler et al. 2003), reflecting poorer $\mathrm{N}$ reserves in young systems, as well as a number of other factors (e.g. irradiance levels, organic matter abundance, and quality) changing in maturing marshes. The microbial community structure is likely to reflect marsh developmental stage, and the primary factors driving changes in the community structure may differ geographically.

This investigation is the first molecular characterization of a diazotrophic salt marsh community in North Carolina. Anaerobic eubacterial and cyanobacterial sequences dominated the community, contrasting communities reported from certain other salt marshes in the United States. To study these differences further, expression studies of $\mathrm{N}_{2}$-fixation genes will be useful in elucidating the environmental controls of diazotrophic communities in different salt marshes.

Acknowledgements. Discussions with C. Currin, T. Steppe, and J. Dyble, and comments from anonymous reviewers are acknowledged. Funding was provided by the University of North Carolina Chapel Hill URC Grant to M.P., an EPA-STAR Grant (R83-0652), and the EPA-STAR-EaGLe Atlantic Coast Environmental Indicators Program (R82867701).

\section{LITERATURE CITED}

Bebout B, Fitzpatrick M, Paerl H (1993) Identification of the sources of energy for nitrogen fixation and physiological characterization of nitrogen-fixing members of a marine microbial mat community. Appl Environ Microbiol 59: 1495-1503

Bergman B, Gallon JR, Rai AN, Stal LJ (1997) $N_{2}$ fixation by non-heterocystous cyanobacteria. FEMS Microbiol Rev 19:139-185

Burris RH, Roberts GP (1993) Biological nitrogen fixation. Annu Rev Nutr 13:317-335

Carpenter EJ, Van Raalte CD, Valiela I (1978) Nitrogen fixation by algae in Massachusetts salt marsh. Limnol Oceanogr 23:318-327

Chien YT, Zinder SH (1994) Cloning, DNA sequencing, and characterization of a nifD homologous gene from the archaeon Methanosarcina barkeri 227 which resembles nifD1 from the eubacterium Clostridium pasteurianum. J Bacteriol 176:6590-6598

Covin J, Zedler JB (1988) Nitrogen effects on Spartina foliosa and Salicornia virginica in the salt marsh at Tijuana Estuary, California. Wetlands 8:51-65

Currin CA, Paerl HW (1998a) Environmental and physiological controls on diel patterns of $\mathrm{N}_{2}$ fixation in epiphytic cyanobacterial communities. Microb Ecol 35:34-45

Currin CA, Paerl HW (1998b) Epiphytic nitrogen fixation associated with standing dead shoots of smooth cordgrass, Spartina alterniflora. Estuaries 21:108-117

Currin CA, Newell SY, Paerl HW (1995) The role of standing dead Spartina alterniflora and benthic microalgae in salt marsh food webs: considerations based on multiple stable isotope analysis. Mar Ecol Prog Ser 121:99-116

Dakora FD, Drake BG (2000) Elevated $\mathrm{CO}_{2}$ stimulates associative $\mathrm{N}_{2}$ fixation in a $\mathrm{C}_{3}$ plant of the Chesapeake Bay wetland. Plant Cell Environ 23:943-953

Gribsholt B, Kristensen E (2003) Benthic metabolism and sulfur cycling along an inundation gradient in a tidal Spartina angelica salt marsh. Limnol Oceanogr 48:2151-2162

Hall TA (1999) BioEdit: a user-friendly biological sequence alignment editor and analysis program for Windows 95/98/NT. Nucl Acids Symp Ser 41:95-98

Hamersley MR, Howes BL (2003) Contribution of denitrification to nitrogen, carbon, and oxygen cycling in tidal creek sediments of a New England salt marsh. Mar Ecol Prog Ser 262:55-69

Jones K (1982) Nitrogen fixation in the temperate estuarine intertidal sediments of the River Lune. Limnol Oceanogr $27: 455-460$

Komárek J (2003) Coccoid and colonial cyanobacteria. In: Wehr JD, Sheath RD (eds) Freshwater algae of North America: ecology and classification. Academic Press, San Diego, CA, p 59-116

Komárek J, Kling H, Komárková J (2003) Filamentous cyanobacteria. In: Wehr JD, Sheath RD (eds) Freshwater algae of North America: ecology and classification. Academic Press, San Diego, CA, p 117-196

Langis R, Zalejko M, Zedler JB (1991) Nitrogen assessments in a constructed and a natural salt-marsh of San Diego Bay. Ecol Appl 1:40-51

Lovell CR, Piceno YM, Quattro JM, Bagwell CE (2000) Molecular analysis of diazotroph diversity in the rhizosphere of the smooth cordgrass, Spartina alterniflora. Appl Environ Microbiol 66:3814-3822

Lovell CR, Friez MJ, Longshore JW, Bagwell CE (2001) Recovery and phylogenetic analysis of nifH sequences from diazotrophic bacteria associated with dead above- 
ground biomass of Spartina alterniflora. Appl Environ Microbiol 67:5308-5314

Newell SY, Hopkinson CS, Scott SA (1992) Patterns of nitrogenase activity (acetylene reduction) associated with standing, decaying shoots of Spartina alterniflora. Estuar Coast Shelf Sci 35:127-140

Nielsen LB, Finster K, Welsh DT, Donelly A, Herbert RA, de Wit R, Lomstein BAa (2001) Sulphate reduction and nitrogen fixation rates associated with roots, rhizomes and sediments from Zostera noltii and Spartina maritima meadows. Environ Microbiol 3:63-71

Olson JB, Steppe TF, Litaker RW, Paerl HW (1998) $\mathrm{N}_{2}$-fixing microbial consortia associated with the ice cover of Lake Bonney, Antarctica. Microb Ecol 36:231-238

Paerl HW, Prufert LE (1987) Oxygen-poor microzones as potential sites of microbial $\mathrm{N}_{2}$-fixation in nitrogendepleted aerobic marine waters. Appl Environ Microbiol 53 1078-1087

Paerl HW, Zehr JP (2001) Nitrogen fixation. In: Kirchman (ed) Microbial ecology of the oceans. Academic Press, New York, p 387-426

Paerl HW, Bebout BM, Currin CA, Fitzpatrick MW, Pinckney JL (1994) Nitrogen fixation dynamics in microbial mats. In: Stal LJ, Caumette P (eds) Microbial mats: structure, development and environmental significance. SpringerVerlag, Berlin, p 325-337

Paul JH (2001) Gene expression by mRNA analysis. Methods Microbiol 30:395-408

Piehler MF, Currin CA, Cassanova R, Paerl HW (1998) Development and $\mathrm{N}_{2}$-fixing activity of the benthic microbial community in transplanted Spartina alterniflora marshes in North Carolina. Restor Ecol 6:290-296

Postgate J (1987) Nitrogen fixation. Institute of Biology's new studies in biology, 2nd edn. Edward Arnold, Hodder and Stoughton Limited, London

Purdy KJ, Munson MA, Cresswell-Maynard T, Nedwell DB, Embley TM (2003) Use of 16S rRNA-targeted oligo-

Editorial responsibility: Jim W. Ammerman,

New Brunswick, New Jersey, USA nucleotide probes to investigate function and phylogeny of sulphate-reducing bacteria and methanogenic archaea in a UK estuary. FEMS Microbiol Ecol 44: 361-371

Rooney-Varga JN, Genthner BRS, Devereux R, Willis SG, Friedman SD, Hines ME (1998) Phylogenetic and physiological diversity of sulphate-reducing bacteria isolated from a salt marsh sediment. Syst Appl Microbiol 21: $557-568$

Schneegurt MA, Sherman DM, Nayar S, Sherman LA (1994) Oscillating behavior of carbohydrate granule formation and dinitrogen fixation in the cyanobacterium Cyanothece sp. strain ATCC 51142. J Bacteriol 176:1586-1597

Swofford DL (1998) PAUP*. Phylogenetic analysis using parsimony ( ${ }^{*}$ and other methods), Version 4. Sinauer Associates, Sunderland, MA

Tyler AC, Mastronicola TA, McGlathery KJ (2003) Nitrogen fixation and nitrogen limitation of primary production along a natural marsh chronosequence. Oecologia 136: $431-438$

Valiela I (1983) Nitrogen in salt marsh ecosystems. In: Carpenter E, Capone DG (eds) Nitrogen in the marine environment. Academic Press, New York

Welschmeyer NA (1994) Fluorometric analysis of chlorophyll $a$ in the presence of chlorophyll $b$ and pheopigments. Limnol Oceanogr 39:1985-1992

Zehr J, McReynolds L (1989) Use of degenerate oligonucleotide primers for amplification of the nifH gene from the marine cyanobacterium Trichodesmium thiebautii. Appl Environ Microbiol 55:2522-2526

Zehr JP, Mellon M, Braun S, Litaker W, Steppe T, Paerl HW (1995) Diversity of heterotrophic nitrogen fixation genes in a marine cyanobacterial mat. Appl Environ Microbiol 61: $2527-2532$

Zehr JP, Jenkins BD, Short SM, Steward GF (2003) Nitrogenase gene diversity and microbial community structure: a cross-system comparison. Environ Microbiol 5:539-554

Submitted: June 14, 2004; Accepted: April 11, 2005

Proofs received from author(s): May 31, 2005 